\title{
Description of Mogibacterium pumilum gen. nov., sp. nov. and Mogibacterium vescum gen. nov., sp. nov., and reclassification of Eubacterium timidum (Holdeman et al. 1980) as Mogibacterium timidum gen. nov., comb. nov.
}

\author{
Futoshi Nakazawa, ${ }^{1}$ Michiko Sato, ${ }^{1}$ Sergio E. Poco, ${ }^{1}$ Tsuyoshi Hashimura, \\ Tetsuro Ikeda, ${ }^{1}$ Sotos Kalfas, ${ }^{2}$ Göran Sundqvist ${ }^{3}$ and Etsuro Hoshino ${ }^{1}$
}

Author for correspondence: Etsuro Hoshino. Tel: +81 25227 2838. Fax: +81 252270806. e-mail: hoshino@dent.niigata-u.ac.jp

1 Department of Oral Microbiology, School of Dentistry, Niigata University, Niigata, 951-8514, Japan

2 Department of Oral Biology, School of Dentistry, University of Umeå, Sweden

3 Department of Endodontics, School of Dentistry, University of Umeå, Sweden

\begin{abstract}
A new genus, Mogibacterium, is proposed for anaerobic, non-spore-forming, Gram-positive, rod-shaped bacteria which have been isolated from the periodontal pockets of adult human patients with periodontal disease and infected root canals. The novel isolates, strains D2-18', BA11a-f and D5-2 ${ }^{\top}$, were inert in most of the conventional biochemical tests and phenotypically resemble asaccharolytic Eubacterium species. The protein profiles of whole cells on SDS-PAGE gels and Western immunoblotting reaction analysis distinguished these organisms from type strains belonging to the previously described Eubacterium species. The G+C content of the DNA is $\mathbf{4 5 - 4 6 ~ m o l \% ~ f o r ~}$ Mogibacterium pumilum and $46 \mathrm{~mol} \%$ for Mogibacterium vescum. The levels of DNA-DNA relatedness of these new species to other Eubacterium species, including Eubacterium limosum, Eubacterium brachy, Eubacterium lentum, Eubacterium nodatum, Eubacterium saphenum, and the more recently proposed Eubacterium minutum and Eubacterium exiguum (reclassified as Slackia exigua), are less than $2 \%$. The DNA-DNA hybridization value between $M$. pumilum and $M$. vescum was $30 \%$. Eubacterium timidum exhibited DNA homologies with Mogibacterium species which were low (17 and $18 \%$ ) but clearly higher than with all the other Eubacterium species. Phylogenetic analysis based on 16S rRNA gene sequences revealed that the closest phylogenetic neighbour of Mogibacterium species was E. timidum, and that these three species represent a novel lineage distinct from the previously described genera of Gram-positive, rod-shaped bacteria. On the basis of phenotypic characteristics and 16S rRNA gene sequence comparisons, it is also proposed that $E$. timidum is transferred to the genus Mogibacterium gen. nov. as Mogibacterium timidum gen. nov., comb. nov. (type strain ATCC 33093').
\end{abstract}

Keywords: Mogibacterium pumilum gen. nov., sp. nov., Mogibacterium vescum gen. nov., sp. nov., Mogibacterium timidum gen. nov., comb. nov.

\section{INTRODUCTION}

Numerous bacterial strains of Gram-positive, nonsporing, obligately anaerobic rods belonging to the genus Eubacterium have been isolated from human

The GenBank/EMBL/DDBJ accession numbers for the $16 \mathrm{~S}$ rRNA sequences are AB021701 (Mogibacterium pumilum D2-18 $=$ ATCC $700696^{\top}$ ) and AB021702 (Mogibacterium vescum D5-2 ${ }^{\top}=$ ATCC $700697^{\top}$ ). oral cavities, including dental plaque (Hill et al., 1987), periodontal lesions (Holdeman et al., 1980; Martin et al., 1986; Moore et al., 1982, 1985; Uematsu \& Hoshino, 1992; Wade et al., 1992), infected dental pulp (Hoshino et al., 1992; Sato et al., 1993a; Sundqvist, 1976), carious dentine (Ando \& Hoshino, 1990; Edwardsson, 1974; Hoshino, 1985) and dentoalveolar abscesses (Wade et al., 1994). Several species of Eubacterium, particularly asaccharolytic species, 
are associated with moderate and severe periodontitis and are less frequent in the supragingival or subgingival sites of healthy persons (Moore et al., 1983; Wade et al., 1992). In addition, it has been recognized that antibody titres against Eubacterium species in the serum of patients with periodontitis are higher than those of healthy controls, suggesting that these bacteria cause immunological reactions in periodontal lesions (Gunsolley et al., 1990; Slayne \& Wade, 1994; Tew et al., 1985; Tolo \& Jorkjend, 1990; Tolo \& Schenck, 1985). Eubacterium strains have also been isolated from non-oral clinically significant infections, such as head and neck infections, abdominal infection (Brook \& Frazier, 1993), bacteraemia associated with malignancy (Fanstein et al., 1989) and genital tract infection associated with intrauterine devices (Brook, 1983).

The genus Eubacterium is distinguished from other genera mainly on the basis of negative metabolic characteristics (Moore \& Moore, 1986). Because of its broad definition, the genus has historically acted as a repository for a large number of phenotypically diverse organisms (Cheeseman et al., 1996; Nakazawa \& Hoshino, 1993). In addition to their phenotypic heterogeneity, it is reported that the bacterial species belonging to the genus are not phylogenetically homogeneous and several species may be closely related to members of the genus Clostridium (Collins et al., 1994; Willems et al., 1996). In recent studies, many oral asaccharolytic isolates have been described, some of which qualify as members of the genus Eubacterium but could not be assigned to any of the named species (Cheeseman et al., 1996; Poco et al., 1996a, 1996b; Wade et al., 1994; Sato et al., 1993a).

Recently, we have isolated Eubacterium-like strains, D2- $18^{\mathrm{T}}$, BA1 1a-f and D5-2 ${ }^{\mathrm{T}}$, from periodontal pockets and infected root canals. However, these strains could not be classified in any of the established Eubacterium species. These organisms are asaccharolytic and Grampositive rods, grow slowly and resemble Eubacterium timidum in phenotypic characteristics when they are compared with the previously established asaccharolytic bacterial species. There are nine previously established oral asaccharolytic Eubacterium species, namely E. timidum, Eubacterium brachy, Eubacterium nodatum, Eubacterium lentum, Eubacterium saphenum, Eubacterium minutum, Eubacterium exiguum (reclassified as Slackia exigua), Eubacterium tardum and Eubacterium infirmum. These species are unreactive in conventional biochemical tests and difficult to culture because of their slow growth even on artificial media designed for fastidious organisms and requirement for strict anaerobiosis (Uematsu \& Hoshino, 1992). A recent study has shown that reference strains of oral asaccharolytic Eubacterium species, including strains D2-18 ${ }^{\mathrm{T}}$, BA11a-f and D5-2 ${ }^{\mathrm{T}}$, can be distinguished from each other by RFLP analysis of 16S rDNA amplified by PCR (Sato et al., 1993b). To determine the taxonomic position of these novel isolates, we examined their phenotypic and phylogenetic charac- teristics and compared our results with data for previously described reference species. In this paper, we report phenotypic characteristics, including wholecell protein profiles and Western immunoblotting reactions, and the results of DNA-DNA hybridization studies, DNA base composition analysis and $16 \mathrm{~S}$ rRNA gene sequence studies of these organisms. On the basis of these results, we propose a new genus, Mogibacterium gen. nov., and new species, Mogibacterium pumilum sp. nov. and Mogibacterium vescum sp. nov., for these organisms. It is also proposed that E. timidum is transferred to the genus Mogibacterium gen. nov. as Mogibacterium timidum gen. nov., comb. nov.

\section{METHODS}

Bacterial strains. The novel strains D2-18 $8^{\mathrm{T}}$ and D5-2 ${ }^{\mathrm{T}}$ were isolated from human periodontal pockets, and the novel strain BA1la-f was isolated from an infected root canal (Sato et al., 1993b; Slayne \& Wade, 1994). The type strains of previously established asaccharolytic Eubacterium species, together with the more recently proposed species $E$. minutum (Poco et al., 1996b) and E. exiguum (Poco et al., 1996a) were included in this study. E. infirmum and $E$. tardum (Cheeseman et al., 1996) were not examined in this work, but are discussed.

Culture conditions. All the strains were cultured on brainheart infusion (BHI)-blood agar plates under strictly anaerobic conditions for 7-10 $\mathrm{d}$ in an anaerobic glove box (model AZ-Hard; Hirasawa) containing 80\% $\mathrm{N}_{2}, 10 \% \mathrm{H}_{2}$ and $10 \% \mathrm{CO}_{2}$. The bacterial cells were harvested by centrifugation, washed with $10 \mathrm{mM}$ PBS $(136 \mathrm{mM} \mathrm{NaCl}$ in $10 \mathrm{mM}$ sodium phosphate buffer $(\mathrm{pH} \mathrm{7.2)}$ and stored at $-20^{\circ} \mathrm{C}$ until they were used. To ensure strictly anaerobic conditions in the box, the reduction of methyl viologen (at $-446 \mathrm{mV}$ ) was carefully checked whenever experimental procedures were carried out.

Morphological studies. Cellular morphology was determined by examining cells grown on BHI-blood agar plates. Transmission electron microscopy was used for cell wall characterization. Cultures $(48 \mathrm{~h})$ were fixed in a solution of $2.5 \%(\mathrm{v} / \mathrm{v})$ glutaraldehyde in $0.1 \mathrm{M}$ potassium phosphate buffer $(\mathrm{pH} 7 \cdot 4)$ for $1 \mathrm{~h}$ at $4{ }^{\circ} \mathrm{C}$. The cells were centrifuged and washed three times with the same buffer. They were postfixed with $1 \%(\mathrm{v} / \mathrm{v})$ osmic acid for $18 \mathrm{~h}$ at $4{ }^{\circ} \mathrm{C}$ and dehydrated for 10 min each with $50,75,90,95$ and $100 \%$ $(\mathrm{v} / \mathrm{v})$ ethanol. Preparations were washed with $33 \cdot 3,66.6$ and $100 \%(\mathrm{v} / \mathrm{v})$ epoxy resin in propylene oxide for $60 \mathrm{~min}$, and then embedded in $100 \%$ epoxy resin. After hardening, ultrathin sections were cut with a diamond knife and then stained with uranyl acetate and lead citrate. The thin sections were studied with a Hitachi H-600A electron microscope.

Biochemical characteristics. Biochemical reactions were tested by the methods described by Holdeman et al. (1977). End products produced in peptone-yeast extract-glucose (PYG) broth were assayed by gas chromatography as described previously (Hoshino \& Sato, 1986). To examine enzymic profiles of these organisms, a Rapid ID 32A kit (API BioMérieux) was used as recommended by the manufacturer, except that preparations were incubated under strictly anaerobic conditions.

Whole-cell protein profiles. Cellular protein profiles were examined by using the SDS-PAGE procedure as described 
by Laemmli (1970). Approximately $50 \mathrm{mg}$ (wet wt) whole cells were suspended in $150 \mu \mathrm{l}$ lysis buffer containing $4 \%$ (w/v) SDS, $40 \%$ (v/v) glycerol, $10 \%$ (v/v) 2-mercaptoethanol and $0.25 \mathrm{M}$ Tris $/ \mathrm{HCl}(\mathrm{pH}$ 6.8). The suspensions were boiled for $10 \mathrm{~min}$ and then centrifuged at $12000 \mathrm{~g}$ for $10 \mathrm{~min}$. The protein concentration of the supernatant were measured with a protein assay kit (Bio$\mathrm{Rad}$ ). The supernatants (total protein; $10 \mu \mathrm{g}$ per lane) were subjected to electrophoresis on a $12.5 \%$ polyacrylamide gel by using a model KS-8010 Micro slab gel electrophoresis system (Marysol). After electrophoresis, the gel was stained with Coomassie brilliant blue R-250.

Western immunoblotting analysis. Proteins were transferred from SDS-PAGE gels to a nitrocellulose membrane (pore size $0.45 \mu \mathrm{m}$; Bio-Rad) by using the transfer buffer system described by Burnette (1981), in conjunction with the trans blot system (Marysol) at a constant current of $350 \mathrm{~mA}$ for $4 \mathrm{~h}$ with cooling. Membranes were processed with slight modification as described previously (Nakazawa \& Hoshino, 1993). Briefly, a rabbit immune antiserum $(1: 1000)$ was used as first antibody, goat anti-rabbit $\operatorname{IgG}$ conjugated with peroxidase $(1: 1000)$ was used as the second antibody and the colour was then developed.

DNA isolation and DNA base composition. DNA was isolated and purified following a modification of the Marmur protocol (Marmur, 1961; Nakazawa \& Hoshino, 1994). DNA G + C content was determined by HPLC as described by Katayama-Fujimura et al. (1984).

DNA-DNA hybridization analysis. DNA-DNA hybridization was performed by the membrane filter method as described previously (Meyer \& Schleifer, 1978; Nakazawa \& Hoshino, 1993). Briefly, reference DNA was labelled by using a multiprime DNA labelling kit (Amersham) and $\left[\alpha^{32} \mathrm{P}\right] \mathrm{dCTP}$ and then purified with a Nick column (Pharmacia LKB Biotechnology). About $40 \mu \mathrm{g}$ unlabelled single-stranded DNA immobilized on each nitrocellulose membrane filter and $0.015 \mu \mathrm{g}$ labelled reference DNA were reassociated in a solution containing $0.08 \%$ SDS, $0.02 \%$ (w/v) polyvinylpyrrolidone, $0.02 \%$ (w/v) Ficoll 400, BSA (Fraction V; Sigma) and $1 \mathrm{ml} 6 \times \mathrm{SSC}(1 \times \mathrm{SSC}$ is $0.15 \mathrm{M} \mathrm{NaCl}$ plus $15 \mathrm{mM}$ sodium citrate). After incubation overnight at $60^{\circ} \mathrm{C}$, the filters were washed and dried. The radioactivity was measured with a liquid scintillation counter. Triplicate tests were performed for each assay and the results were normalized to $100 \%$ for homologous DNA.

Sequencing of the 16S rRNA gene and phylogenetic analysis. The 16S rRNA gene was amplified by PCR with a nucleotide primer set [5'-AGA GTT TGA TCM TGG CTC AG-3', located at positions 8-27 (Escherichia coli numbering) and 3'-TTC AGC ATT GTT CCA TYG GCAT-5', located at positions 1492-1513 (Escherichia coli numbering)]. The PCR were performed with Premix Taq (Takara) according to the manufacturer's instructions in a thermal controller (model PTC-100; MJ Research). The DNA fragment obtained by PCR amplification was sequenced by using a Thermo Sequenase Fluorescent Labelled Primer Cycle Sequencing kit (Amersham Japan) and a series of custom-synthesized primers with an ALFexpress DNA sequencer (Pharmacia LKB) according to the manufacturer's instructions. The sequences were aligned by using SEQMAN II of the LASERGENE program (DNASTAR). MEGALIGN Of LASERGENE, CLUSTAL W and NJPLOT programs were used to compare sequences and to construct a evolutionary tree by the neighbour-joining method (Saitou \& Nei, 1987). Confidence values were assessed by CLUSTAL W with bootstrap analysis.
Nucleotide sequence accession numbers. The accession numbers of the $16 \mathrm{~S}$ rRNAs sequences of reference strains were: Acetobacterium bakii, X96960; Clostridium acetobutylicum, X78073; Clostridium acidiurici, M59084; 'Clostridium aminobutyricum', X76161; Clostridium beijerinckii, X68180; Clostridium bifermentans, X73437; Clostridium difficile, X73450; Clostridium felsineum, X77851; Clostridium formicoaceticum, X77836; Clostridium ghoni, X73451; Clostridium glycolicum, X76750; Clostridium innocuum, M23732; Clostridium irregularis, X73447; Clostridium litorale, X77845; Clostridium paradoxum, Z69934; Clostridium propionicum, X77841; Clostridium purinolyticum, M60491; Clostridium sordellii, M59105; Clostridium villosum (reclassified as Filifactor villosus), X73452; Eubacterium barkeri, M23927; Eubacterium biforme, M59230; Eubacterium brachy, Z36272; Eubacterium callanderi, X96961; Eubacterium cellulosolvens, L34613; Eubacterium infirmum, U13039; Eubacterium limosum, M59120; Eubacterium minutum, AJ005636; Eubacterium nodatum, U13041; Eubacterium saphenum, U65987; Eubacterium tardum, U13037; Eubacterium tenue, M59118; 'Eubacterium thermomarinus', L10086; Eubacterium timidum, Z36296; Peptostreptococcus anaerobius, L04168; Peptostreptococcus asaccharolyticus, D14138; and Peptostreptococcus micros, D14143.

\section{RESULTS AND DISCUSSION}

\section{Colony and cell morphology}

Colonies visible by eye of novel strains D2-18 $8^{\mathrm{T}}$ and BA11a-f, and D5-2 $2^{\mathrm{T}}$ (classified as M. pumilum and $M$. vescum, respectively, on the basis of the results given below) appeared on BHI-blood agar after $2 \mathrm{~d}$ incubation. After 4-6 d, the colonies were circular, convex, translucent, had a smooth surface and were about $0.4-0.6 \mathrm{~mm}$ in diameter. Even after prolonged incubation, the colonies were less than $1 \mathrm{~mm}$ in diameter. No haemolysis occured around colonies of these strains on BHI-blood agar plates. The strains were non-sporing, non-motile, short, rod-shaped organisms, occurring mostly as single cells, but sometimes in pairs, short chains or clumps. The growing cells were $0.2-0.3 \mu \mathrm{m} \times 1.0-1.5 \mu \mathrm{m}$ in size and Grampositive, but sometimes cells in older cultures were Gram-negative. The organisms are very difficult to culture in broth media because of their poor growth with or without carbohydrates even on fastidious artificial media, and their requirement for strict anaerobiosis, both of which are characteristics typical of oral asaccharolytic Eubacterium species.

Electron micrographs of ultrathin sections of $M$. pumilum $\mathrm{D} 2-18^{\mathrm{T}}$ and $M$. vescum $\mathrm{D} 5-2^{\mathrm{T}}$ revealed a cell wall architecture typical of Gram-positive bacteria, including a plasma membrane layer, thin peptidoglycan layer in the middle and a thicker outer layer (Fig. 1).

\section{Phenotypic analysis}

These organisms were asaccharolytic because they did not ferment glucose and other carbohydrates, and were inert in most of the conventional biochemical 

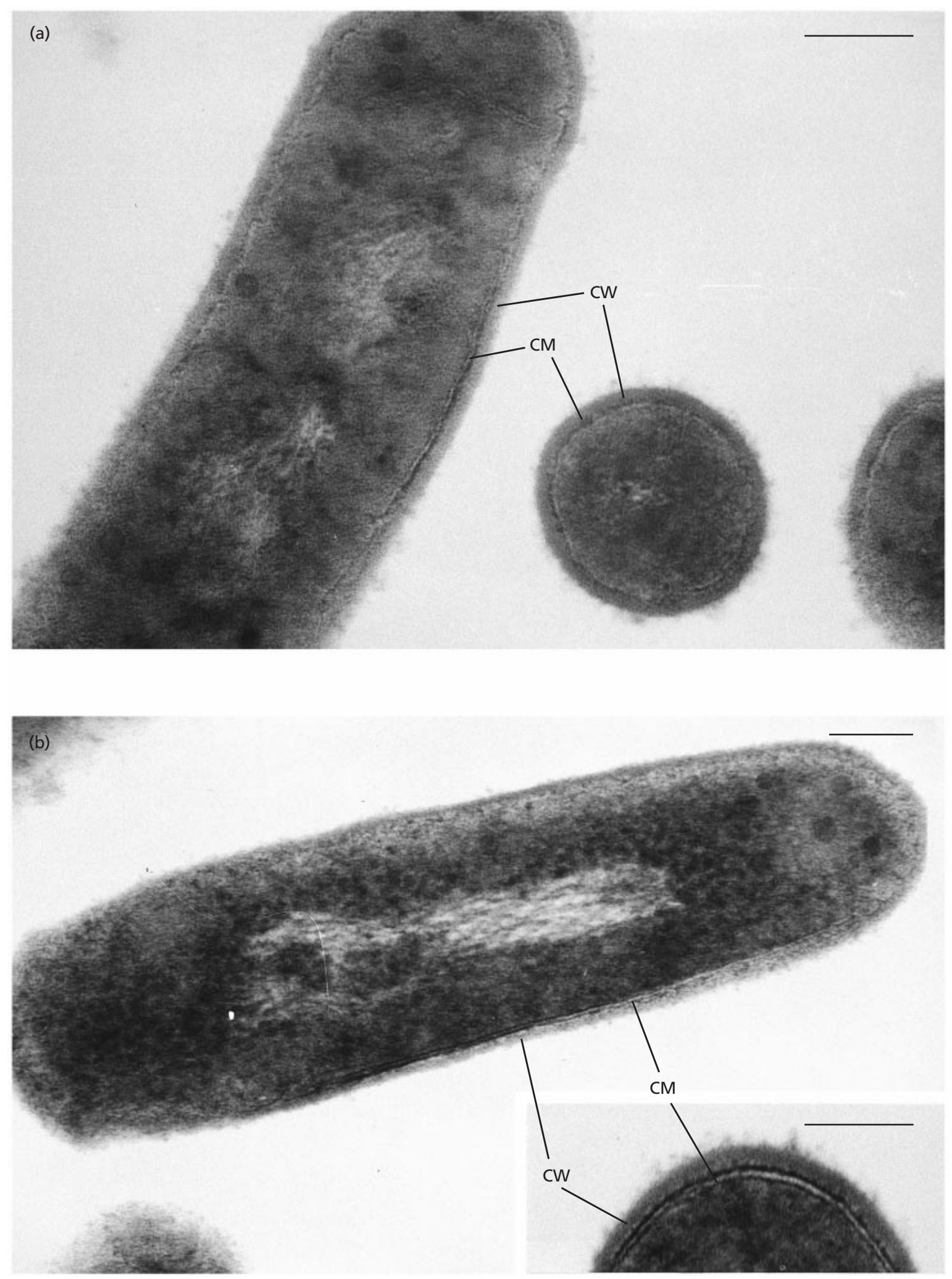

Fig. 1. Transmission electron microphotographs of thin sections of cells of Mogibacterium species showing the Grampositive cell wall. The cell wall (CW) and cytoplasmic membrane (CM) are indicated. (a) Mogibacterium pumilum D2-18 (= ATCC 700696 $)$; (b) Mogibacterium vescum D5-2 ${ }^{\top}$ (= ATCC 700697 $)$. Bars, $100 \mathrm{~nm}$. 
Table 1. Biochemical characteristics of Mogibacterium and Eubacterium species

\begin{tabular}{|c|c|c|c|}
\hline Taxon & $\begin{array}{l}\text { End products } \\
\text { from PYG* }\end{array}$ & $\begin{array}{l}\text { Arginine } \\
\text { hydrolysis }\end{array}$ & $\begin{array}{c}\text { Nitrate } \\
\text { reduction }\end{array}$ \\
\hline Mogibacterium pumilum $\mathrm{D} 2-18^{\mathrm{T}}$ & phe-a & - & - \\
\hline Mogibacterium pumilum BA11a-f & phe-a & - & - \\
\hline Mogibacterium vescum D5- $2^{\mathrm{T}}$ & phe-a & - & - \\
\hline $\begin{array}{l}\text { Mogibacterium (Eubacterium) timidum ATCC } \\
33093^{\mathrm{T}}\end{array}$ & phe-a & - & - \\
\hline $\begin{array}{l}\text { Eubacterium exiguum (Slakia exigua) ATCC } \\
700122^{\mathrm{T}}\end{array}$ & - & + & - \\
\hline $\begin{array}{l}\text { Eubacterium lentum (Eggerthella lenta) ATCC } \\
25559^{\mathrm{T}}\end{array}$ & - & + & + \\
\hline Eubacterium minutum ATCC $700079^{\mathrm{T}}$ & $\mathrm{B}$ or $\mathrm{b}$ & - & - \\
\hline Eubacterium nodatum ATCC $33099^{\mathrm{T}}$ & $\mathrm{a}, \mathrm{B}$ & + & - \\
\hline Eubacterium saphenum ATCC $49989^{\mathrm{T}}$ & $a, b$ & - & - \\
\hline Eubacterium brachy ATCC $33089^{\mathrm{T}}$ & ib, ic, iv, phe-p & - & - \\
\hline
\end{tabular}

*a, Acetate; b, butyrate; ib, isobutyrate; ic, isocaproate; iv, isovalerate; phe-a, phenyl acetate; phe$\mathrm{p}$, phenyl propionate. Capital letters represent an amount of product equal or more than $10 \mathrm{mM}$ and small letters represent an amount less than $10 \mathrm{mM}$.

tests. They were nitrate-reduction-negative and did not hydrolyse aesculin, starch, arginine or gelatin. They also did not produce indole, ammonia, urease or catalase. They produced phenyl acetate as the sole metabolic end product in PYG medium, as assayed by gas chromatography (Table 1). Among the previously described oral asaccharolytic Eubacterium species, they phenotypically resembled E. timidum, which also produces phenyl acetate as an end product. They are phenotypically distinct from the acetate- and butyrateproducing asaccharolytic Eubacterium species (Table $1)$ such as $E$. brachy, E. nodatum, E. saphenum, $E$. minutum, E. tardum and E. infirmum (Cheeseman et al., 1996). The enzymic activities of these strains showed a profile (API code 0000020000 ) including a positive reaction in the aminopeptidase and proline arylamidase tests, which was the same as that reported by Cheeseman et al. (1996) for E. timidum. The previously described oral asaccharolytic Eubacterium species, including the recently proposed species, $E$. minutum, $E$. exiguum, E. tardum and E. infirmum, each showed quite typical enzymic profiles (Cheeseman et al., 1996; Poco et al., 1996a, b).

In the whole-cell protein profiles examined by SDSPAGE, M. pumilum D2-18 $8^{\mathrm{T}}$ had a major band in the region of about $30 \mathrm{kDa}$, whilst $M$. vescum $\mathrm{D} 5-2^{\mathrm{T}}$ had major bands of about 55, 45 and $30 \mathrm{kDa}$ (data not shown). These oral asaccharolytic bacteria, including Eubacterium species examined in the present study, namely E. exiguum, E. lentum, E. brachy, E. nodatum, E. timidum, E. minutum, E. saphenum, $M$. vescum and $M$. pumilum, each showed typical protein profiles and no major bands were common, indicating great heterogeneity in the whole-cell protein components. Western immunoblotting reactions with rabbit antisera revealed that antigens of $M$. pumilum and $M$. vescum did not react with the antisera against the reference oral asaccharolytic species, whilst antigens from the previously described species were recognized by their respective antisera (data not shown). These results clearly showed that $M$. pumilum and $M$. vescum could be distinguished from the reference species by their protein components, including the structural proteins of the whole bacterial cells, and by their immunological reactions. These data are also consistent with the previously published data of Nakazawa \& Hoshino (1993).

\section{Genotypic analysis}

As previously reported, the DNA $\mathrm{G}+\mathrm{C}$ contents of oral asaccharolytic Eubacterium species range from 38 to $62 \mathrm{~mol} \%$ (Nakazawa \& Hoshino, 1994; Poco et al., $1996 \mathrm{a}, \mathrm{b})$. The $\mathrm{G}+\mathrm{C}$ contents of $M$. pumilum strains $\mathrm{D} 2-18^{\mathrm{T}}$ and BA11a-f, and M. vescum strain D5-2 were 46,45 and $46 \mathrm{~mol} \%$, respectively (Table 2), which are similar to E. saphenum and E. tardum (Cheeseman et al., 1996; Uematsu et al., 1993) but are clearly distinguishable from the other Eubacterium species, E. brachy, E. nodatum, E. minutum, E. lentum, E. timidum, E. exiguum, E. infirmum and E. limosum, which is the type species of the genus Eubacterium (Table 2).

The levels of DNA relatedness estimated by quantitative DNA-DNA hybridization studies with the membrane filter method are listed in Table 2. The DNA of M. pumilum strain D2-18 $8^{\mathrm{T}}$ exhibited a very high level of reassociation with the DNA of the strain BA11a-f (97\%), clearly suggesting that they belong to the same bacterial species. On the other hand, $M$. vescum strain D5-2 ${ }^{\mathrm{T}}$ showed $31 \%$ DNA reassociation with $M$. pumilum strain D2-18 ${ }^{\mathrm{T}}$. Moreover, these 
Table 2. DNA base compositions and levels of DNA relatedness

\begin{tabular}{|c|c|c|c|c|}
\hline \multirow[t]{2}{*}{ Source of DNA } & \multirow[t]{2}{*}{$\begin{array}{c}G+C \text { content } \\
(\mathrm{mol} \%)\end{array}$} & \multicolumn{3}{|c|}{$\begin{array}{l}\% \text { Homology } \\
\text { with labelled } \\
\text { DNA from:* }\end{array}$} \\
\hline & & D2-18 & D5-2 ${ }^{\mathrm{T}}$ & $33093^{\mathrm{T}}$ \\
\hline Mogibacterium pumilum D2-18 & 46 & 100 & & \\
\hline Mogibacterium pumilum BA11a-f & 45 & 97 & & \\
\hline Mogibacterium vescum D5-2 ${ }^{\mathrm{T}}$ & 46 & 31 & 100 & \\
\hline Mogibacterium (Eubacterium) timidum ATCC $33093^{\mathrm{T}}$ & 50 & 17 & 18 & 100 \\
\hline $\begin{array}{l}\text { Eubacterium exiguum (Slackia exigua) ATCC } \\
700122^{\mathrm{T}}\end{array}$ & 60 & 2 & 3 & 2 \\
\hline Eubacterium minutum ATCC $700079^{\mathrm{T}}$ & $38-40$ & 2 & 3 & 2 \\
\hline Eubacterium nodatum ATCC $33099^{\mathrm{T}}$ & 41 & 2 & 2 & 2 \\
\hline $\begin{array}{l}\text { Eubacterium lentum (Eggerthella lenta) ATCC } \\
25559^{\mathrm{T}}\end{array}$ & 62 & 1 & 2 & 3 \\
\hline Eubacterium brachy AТCC $33089^{\mathrm{T}}$ & 39 & 2 & 2 & 2 \\
\hline Eubacterium saphenum ATCC $49989^{\mathrm{T}}$ & 45 & 2 & 2 & 1 \\
\hline Eubacterium limosum ATCC $8486^{\mathrm{T}}$ & 50 & 2 & 1 & 1 \\
\hline
\end{tabular}

* All values were normalized to $100 \%$ for the homologous reactions.

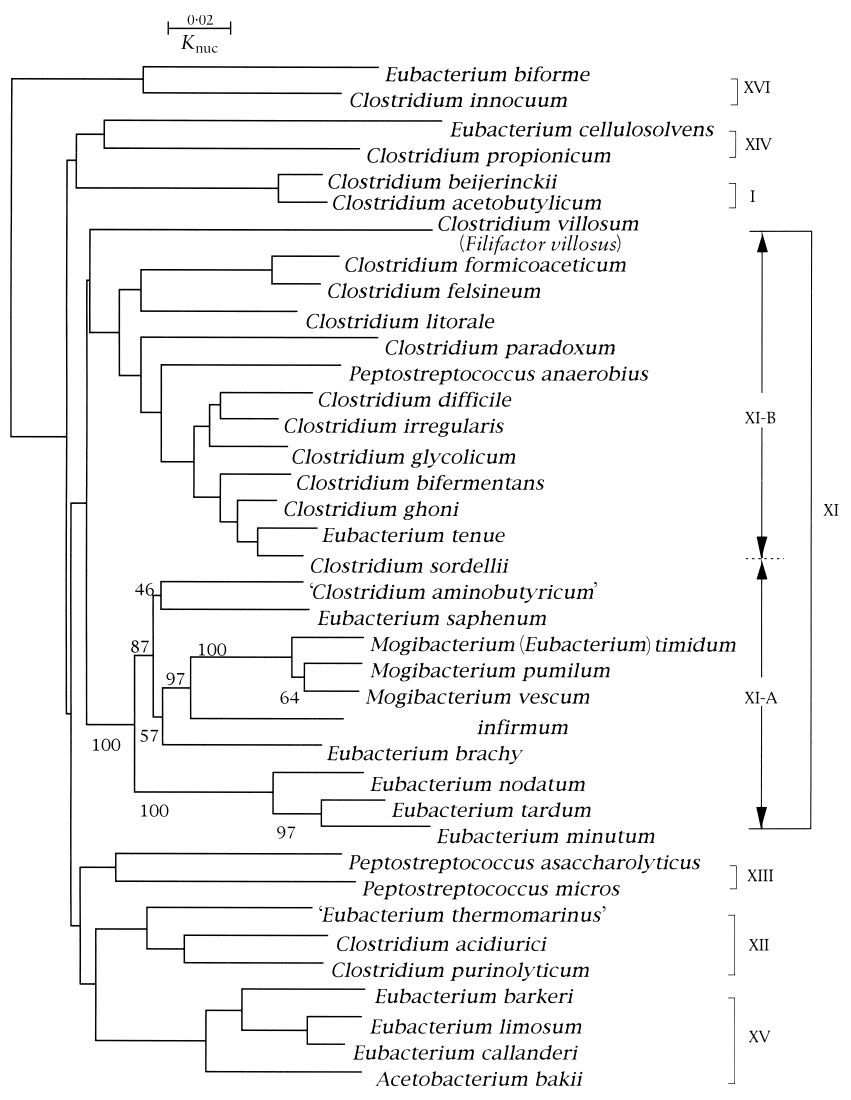

Fig. 2. Evolutionary tree based on $16 \mathrm{~S}$ rRNA gene sequence comparisons, showing the phylogenetic positions of Mogibacterium pumilum (D2-18 ${ }^{\top}=$ ATCC $\left.700696^{\top}\right)$ and Mogibacterium vescum $\left(\mathrm{D} 5-2^{\top}=\right.$ ATCC $\left.700697^{\top}\right)$. The dendrogram was created by using the neighbour-joining method. The numbers on the tree indicate percentage bootstrap values calculated from 1000 replications. Nucleotide sequence accession numbers are given in the text.
Mogibacterium species showed very low levels $(<2 \%)$ of DNA reassociation with the oral asaccharolytic Eubacterium species, including the type species of the genus Eubacterium, E. limosum, except E. timidum (Table 2). The DNA-DNA hybridization values between Mogibacterium species and E. timidum were 17 and $18 \%$, which were clearly higher than all the other Eubacterium species. Johnson (1984) has proposed that groups of bacteria with intragroup DNA homology of $80-90 \%$ and intergroup homology between 60 and $70 \%$ could be considered different subspecies within a species. Johnson (1984) also stated that strains showing homology between 20 and $60 \%$ could be considered closely related species. These criteria, taken with the DNA-DNA hybridization data in the present study, suggest that these novel strains may be assigned to a genus different from the genus Eubacterium, and strain D2-18 ${ }^{\mathrm{T}}$ may belong to the same species as strain BA11a-f whilst strain D5-2 ${ }^{\mathrm{T}}$ belongs to a second species. These DNA homology data also suggest that E. timidum may be related to Mogibacterium species.

\section{Phylogenetic analysis}

The 16S rRNA gene sequences of $M$. pumilum strain D2-18 (length, 1470 bases) and M. vescum strain D5$2^{\mathrm{T}}$ (length, 1477 bases) were determined in order to assess the phylogenetic positions of the organisms. The sequences were also compared with those of related Gram-positive bacteria which were selected from GenBank database by the BLAST and FASTA algorithms. The database search revealed that M. pumilum D2-18 ${ }^{\mathrm{T}}$ and $M$. vescum $\mathrm{D} 5-2^{\mathrm{T}}$ belong to the Clostridium subphylum of the Gram-positive bacteria and that their 16S rRNA sequences are most similar to those of members of Clostridium cluster XI (Collins et al., 
Table 3. Levels of $16 \mathrm{~S}$ rDNA sequence similarity of Mogibacterium species and Eubacterium limosum to other Eubacterium species and other members of subcluster $\mathrm{XI}-\mathrm{A}$

\begin{tabular}{|c|c|c|c|c|}
\hline \multirow[t]{2}{*}{ Bacterial species } & \multicolumn{4}{|c|}{ Percentage similarity with: } \\
\hline & M. pumilum & M. vescum & M. timidum & E. limosum \\
\hline Mogibacterium pumilum & $100 \cdot 0$ & & & \\
\hline Mogibacterium vescum & $95 \cdot 8$ & $100 \cdot 0$ & & \\
\hline Mogibacterium (Eubacterium) timidum & $92 \cdot 7$ & $92 \cdot 3$ & $100 \cdot 0$ & \\
\hline Eubacterium limosum & $72 \cdot 0$ & $71 \cdot 9$ & $70 \cdot 2$ & $100 \cdot 0$ \\
\hline Eubacterium infirmum & $83 \cdot 9$ & $84 \cdot 3$ & $82 \cdot 5$ & $73 \cdot 0$ \\
\hline Eubacterium saphenum & $83 \cdot 5$ & $83 \cdot 5$ & $83 \cdot 5$ & $76 \cdot 1$ \\
\hline Eubacterium brachy & $83 \cdot 3$ & $82 \cdot 9$ & $83 \cdot 8$ & $70 \cdot 9$ \\
\hline Eubacterium minutum & $79 \cdot 8$ & $79 \cdot 9$ & $80 \cdot 1$ & $74 \cdot 0$ \\
\hline Eubacterium nodatum & $79 \cdot 6$ & $78 \cdot 7$ & $78 \cdot 6$ & $74 \cdot 2$ \\
\hline Eubacterium tardum & $75 \cdot 8$ & $78 \cdot 2$ & $79 \cdot 1$ & $72 \cdot 6$ \\
\hline 'Eubacterium thermomarinus' & $74 \cdot 3$ & $74 \cdot 3$ & $72 \cdot 9$ & $78 \cdot 6$ \\
\hline Eubacterium tепие & $72 \cdot 4$ & $73 \cdot 0$ & $71 \cdot 0$ & $73 \cdot 8$ \\
\hline Eubacterium callanderi & $71 \cdot 0$ & $71 \cdot 1$ & $71 \cdot 0$ & $97 \cdot 6$ \\
\hline Eubacterium barkeri & $70 \cdot 7$ & $71 \cdot 0$ & $69 \cdot 9$ & $91 \cdot 7$ \\
\hline Eubacterium cellulosolvens & $68 \cdot 4$ & $68 \cdot 6$ & $67 \cdot 7$ & $73 \cdot 3$ \\
\hline Eubacterium biforme & $65 \cdot 1$ & $65 \cdot 6$ & $65 \cdot 7$ & $64 \cdot 9$ \\
\hline 'Clostridium aminobutyricum' & $84 \cdot 5$ & $84 \cdot 9$ & $83 \cdot 1$ & $74 \cdot 4$ \\
\hline
\end{tabular}

1994). A phylogenetic analysis was performed including all taxa from cluster XI, other Eubacterium species and representatives of other clostridial clusters defined by Collins et al. (1994). On the basis of the sequence similarity matrix data, an evolutionary tree was constructed by MEGALIGN using the neighbourjoining method (Saitou \& Nei, 1987) and is shown in Fig. 2.

Our analysis indicates that the cluster XI may be divided into two subclusters, XI-A and XI-B, and that $M$. pumilum and $M$. vescum are members of the subcluster XI-A (Fig. 2). Although oral asaccharolytic Eubacterium species examined in the present study also belong to the subcluster XI-A, M. pumilum and $M$. vescum could be distinguished from these species. The closest phylogenetic neighbour of Mogibacterium species is E. timidum, and these three species form a branch in the phylogenetic tree. These three species had no close phylogenetic affinities with the other members of the subcluster XI-A (sequence similarities $<84.9 \%$; sequence divergence values $>12.2 \%$ ) when compared directly with these taxa (Table 3). These data are consistent with the results of DNA-DNA hybridization and biochemical characterization studies (Tables 1 and 2). Our phylogenetic analysis based on 16S rRNA gene sequences indicates that $M$. pumilum, $M$. vescum and E. timidum are not closely related to not only other asaccharolytic Eubacterium but also to other taxa established previously, which is consistent with the creation of a new genus and species. These data agree with previous results obtained by RFLP analysis of $16 \mathrm{~S}$ rDNA from oral asaccharolytic Eubacterium species (Sato et al., 1993b).
E. timidum showed $16 \mathrm{~S}$ rRNA sequence similarities of 92.7 and $92.3 \%$ to the sequences of $M$. pumilum and $M$. vescum, respectively (Table 3 ). These similarities may be considered low for the same genus, but there is no strict guideline on the level of similarity for genera. According to the topology of the phylogenetic tree and DNA-DNA hybridization data, together with the phenotypic similarity, it seems quite reasonable to transfer E. timidum to Mogibacterium.

On the other hand, E. limosum, which is the type species of the genus Eubacterium, showed very low levels of sequence similarity $(<78.6 \%)$ to other Eubacterium species except E. callanderi $(97 \cdot 6 \%)$ and E. barkeri $(91.6 \%)$, as shown in Table 3. These similarity data and the phylogenetic tree (Fig. 2) indicate that the genus Eubacterium may be incoherent and $E$. limosum is remotely related to other Eubacterium species phylogenetically, as reported by several authors (Cheeseman et al., 1996; Nakazawa \& Hoshino, 1993, 1994; Wade et al., 1994). The results also suggest that some of the other Eubacterium species, especially asaccharolytic ones, i.e. $E$. saphenum, E. infirmum, $E$ brachy, E. nodatum, $E$. tardum and E. minutum, may need reassignment to different genera, which is in agreement with the our previous study (Nakazawa \& Hoshino, 1994). In fact, E. exiguum and E. lentum were recently reclassified in new genera, Slakia exigua and Eggerthella lenta, respectively (Wade et al., 1999).

At the present time, we have no information on the distribution or incidence of these bacteria in human mouths. Studies of cell wall composition and anti- 
microbial susceptibility, which may be helpful for description of Mogibacterium species, will be investigated in our ongoing future research. On the basis of biochemical characteristics, SDS-PAGE and Western immunoblotting analyses, $\mathrm{G}+\mathrm{C}$ content determination, DNA-DNA hybridization data and phylogenetic analysis with $16 \mathrm{~S}$ rRNA gene sequence data, we propose a new genus, Mogibacterium, and new species, $M$. pumilum for strain D2-18 $8^{\mathrm{T}}$ and BA11a-f, and $M$. vescum for strain D5-2 ${ }^{\mathrm{T}}$. It is also proposed that Eubacterium timidum is transferred to the genus Mogibacterium gen. nov. as Mogibacterium timidum gen. nov., comb. nov. The taxonomic description below summarizes the properties of these species.

\section{Description of Mogibacterium gen. nov.}

Mogibacterium (Mogi.bac.te'ri.um. Gr. n. mogi difficult; Gr. n. bakterion a small rod; M.L. neut. n. Mogibacterium a difficult-to-culture, rod-shaped bacterium).

Cells are Gram-positive and rod-shaped. No spores are formed. Non-motile. Strictly anaerobic and asaccharolytic. Growth in broth media is very poor. Catalase-negative. Metabolic end product in PYG medium is phenyl acetate. The DNA base composition is $45-46 \mathrm{~mol} \% \mathrm{G}+\mathrm{C}$. Members of the genus Mogibacterium can be distinguished from each other by $16 \mathrm{~S}$ rRNA gene sequences and DNA homology values. The type species is Mogibacterium pumilum.

\section{Description of Mogibacterium pumilum sp. nov.}

Mogibacterium pumilum (pu.mi'lum. L. adj. pumilum small or tiny, referring to the tiny colonies formed by this organism).

Cells are short, Gram-positive rods, obligately anaerobic, non-motile and non-sporing. Individual cells are about $0.2-0.3$ by $1.0 \mu \mathrm{m}$, occurring singly, in short chains or in clumps. On BHI-blood agar plates they form minute colonies $<1 \mathrm{~mm}$ in diameter even after prolonged incubation in an anaerobic glove box, which are circular, convex and translucent. Growth in PY broth media is very poor with or without carbohydrates. No haemolysis occurs around colonies on BHI-blood agar plates. The cells are inert in most biochemical tests. Starch and aesculin are not hydrolysed and nitrate is not reduced. No liquefaction of gelatin occurs. Indole, urease and catalase tests are also negative. Ammonia is not produced from arginine. All strains are nonfermentative and do not utilize adonitol, amygdalin, arabinose, cellobiose, erythritol, aesculin, fructose, galactose, glucose, glycogen, inositol, lactose, maltose, mannitol, mannose, melezitose, melibiose, rhamnose, ribose, salicin, sorbitol, starch, sucrose, trehalose or xylose. They produce phenyl acetate (about $3 \mathrm{mM}$ ) as the sole metabolic end product in PY or PYG broth. The $\mathrm{G}+\mathrm{C}$ content is $45-46 \mathrm{~mol} \%$. The type strain is D2-18 ${ }^{\mathrm{T}}$ (=
ATCC $700696^{\mathrm{T}}$ ). Isolated from human periodontal pockets.

\section{Description of Mogibacterium vescum sp. nov.}

Mogibacterium vescum (ves'cum. L. adj. vescum weak, referring to the poor growth of this organism).

Cells are short, Gram-positive rods, obligately anaerobic, non-motile and non-sporing. Individual cells are about $0 \cdot 2-0 \cdot 3$ by $1.5 \mu \mathrm{m}$, occurring singly or in clumps. On BHI-blood agar plates they form minute colonies $<1 \mathrm{~mm}$ in diameter even after prolonged incubation in an anaerobic glove box, which are circular, convex and translucent. Growth in broth media is poor with or without carbohydrates. No haemolysis occurs around colonies on BHI-blood agar plates. The cells are nonfermentative and do not utilize adonitol, amygdalin, arabinose, cellobiose, erythritol, aesculin, fructose, galactose, glucose, glycogen, inositol, lactose, maltose, mannitol, mannose, melezitose, melibiose, rhamnose, ribose, salicin, sorbitol, starch, sucrose, trehalose or xylose. Catalase, urease and indole are not produced, and ammonia is not produced from arginine. They produce phenyl acetate $(4 \mathrm{mM})$ as the sole metabolic end product in PY or PYG broth. The $\mathrm{G}+\mathrm{C}$ content is $46 \mathrm{~mol} \%$. This strain can be distinguished from Mogibacterium pumilum according to the almost complete sequence of the $16 \mathrm{~S}$ rRNA gene and DNA relatedness values. The type strain is $\mathrm{D} 5-2^{\mathrm{T}}\left(=\mathrm{ATCC} 700697^{\mathrm{T}}\right)$. Isolated from human periodontal pockets.

\section{Description of Mogibacterium timidum (Eubacterium timidum Holdeman et al. 1980) comb. nov.}

M. timidum (ti'mi.dum. L. neut. adj. timidum fearful, timid, referring to the slight or slow growth in clumps).

Characteristics of the species are as previously described by Holdeman et al. (1980). The type strain is ATCC $33093^{\mathrm{T}}$.

\section{ACKNOWLEDGEMENTS}

This study was supported in part by grants-in-aid for scientific research 06044082, 07807166, 09470390, 99174 and 10922050 from the Ministry of Education, Science and Culture of Japan.

\section{REFERENCES}

Ando, N. \& Hoshino, E. (1990). Predominant obligate anaerobes invading the deep layers of root canal dentine. Int Endod $J$ 23, 20-27.

Brook, I. (1983). Anaerobic bacterial bacteremia: 12-year experience in two military hospitals. J Infect Dis 160, 1071-1075.

Brook, I. \& Frazier, E. H. (1993). Significant recovery of nonsporulating anaerobic rods from clinical specimens. Clin Infect Dis 16, 476-480.

Burnette, W. N. (1981). Western blotting electrophoretic transfer 
from sodium dodecyl sulfate-polyacrylamide gels to unmodified nitrocellulose and radiographic detection with antibody and radio-iodinated protein A. Anal Biochem 112, 195.

Cheeseman, S., Hiom, S., Weightman, A. \& Wade, W. G. (1996). Phylogeny of oral asaccharolytic Eubacterium species determined by $16 \mathrm{~S}$ ribosomal DNA sequence comparison and proposal of Eubacterium infirmum sp. nov. and Eubacterium tardum sp. nov. Int J Syst Bacteriol 46, 957-959.

Collins, M. D., Lawson, P. A., Willems, A., Cordoba, J. J., Fernandez-Garayzabal, J., Garcia, P., Cai, J., Hippe, H. \& Farrow, J. A. E. (1994). The phylogeny of the genus Clostridium: proposal of new genera and eleven new species combinations. Int $J$ Syst Bacteriol 44, 812-826.

Edwardsson, S. (1974). Bacteriological studies on deep areas of carious dentine. Odontol Revy 25 (suppl. 32), 1-143.

Fanstein, V., Elting, L. S. \& Bodey, G. P. (1989). Bacteremia caused by non-sporulating anaerobes in cancer patients. Medicine 68, 151-162.

Gunsolley, J. C., Gooss, C., Marshall, D. R., Burmeister, J. A. \& Schenkein, H. A. (1990). Serum antibodies to periodontal bacteria. J Periodontol 61, 412-419.

Hill, G. B., Ayers, O. M. \& Kohhan, A. P. (1987). Characteristics and sites of infection of Eubacterium nodatum, Eubacterium timidum, Eubacterium brachy, and other asaccharolytic eubacteria. J Clin Microbiol 25, 1540-1545.

Holdeman, L. V., Cato, E. P. \& Moore, W. E. C. (editors) (1977). Anaerobe Laboratory Manual, 4th edn. Blacksburg: Virginia Polytechnic Institute and State University.

Holdeman, L. V., Cato, E. P., Burmeister, E. P. \& Moore, W. E. C. (1980). Description of Eubacterium timidum sp. nov., Eubacterium brachy sp. nov. and Eubacterium nodatum sp. nov., isolated from human periodontitis. Int J Syst Bacteriol 30, $163-169$

Hoshino, E. (1985). Predominant obligate anaerobes in human carious dentin. J Dent Res 64, 1195-1198.

Hoshino, E. \& Sato, M. (1986). Production and degradation of formate by Veillonella dispar ATCC 17745. J Dent Res 65, 903-905.

Hoshino, E., Ando, N., Sato, M. \& Kato, K. (1992). Bacterial invasion of non-exposed pulp. Int Endod J 25, 2-5.

Johnson, J. L. (1984). Nucleic acid in bacterial classification. In Bergey's Manual of Systematic Bacteriology, vol. 2, pp. 972-975. Edited by P. H. A. Sneath, N. S. Mair, M. E. Sharpe \& J. G. Holt. Baltimore: Williams \& Wilkins.

Katayama-Fujimura, Y., Komatsu, Y., Kuraishi, H. \& Kaneko, T. (1984). Estimation of DNA base composition by high performance liquid chromatography of its nuclease P1 hydrolysate. Agric Biol Chem 48, 3169-3172.

Laemmli, U. K. (1970). Cleavage of structural proteins during the assembly of the head of bacteriophage T4. Nature 227, 680-685.

Marmur, J. (1961). A procedure for the isolation of DNA from microorganisms. J Mol Biol 3, 208-218.

Martin, S. A., Falker, W. A., Vincent, J. W., Mackler, B. F. \& Suzuki, J. B. (1986). A comparison of the reactivity of Eubacterium species with localized and serum immunoglobulins from rapidly progressive and adult periodontitis. $J$ Periodontol 59, 32-39.

Meyer, S. A. \& Schleifer, K. H. (1978). Deoxyribonucleic acid reassociation in the classification of coagulase-positive staphylococci. Arch Microbiol 117, 183-188.

Moore, W. E. C. \& Moore, L. V. H. (1986). Genus Eubacterium
Prévot 1938, 294 ${ }^{\mathrm{AL}}$. In Bergey's Manual of Systematic Bacteriology, vol. 2, pp. 1353-1373. Edited by P. H. A. Sneath, N. S. Mair, M. E. Sharpe \& J. G. Holt. Baltimore: Williams \& Wilkins.

Moore, W. E. C., Holdeman, L. V., Smibert, R. M., Hash, D. E., Burmeister, J. A. \& Ranney, R. R. (1982). Bacteriology of severe periodontitis in young adults. Infect Immun 38, 1137-1145.

Moore, W. E. C., Holdeman, L. V., Burmeister, J. A. \& Ranney, R. R. (1983). Bacteriology of moderate (chronic) periodontitis in mature adult humans. Infect Immun 42, 510-515.

Moore, W. E. C., Holdeman, L. V., Cato, E. P., Smibert, R. M., Burmeister, J. A., Palcanis, K. G. \& Ranney, R. R. (1985). Comparative bacteriology of juvenile periodontitis. Infect Immun $\mathbf{4 8}$, 507-519.

Nakazawa, F. \& Hoshino, E. (1993). Immunological specificity of oral Eubacterium species. J Gen Microbiol 139, 2635-2640.

Nakazawa, F. \& Hoshino, E. (1994). Genetic relationships among Eubacterium species. Int J Syst Bacteriol 44, 787-790.

Poco, S. E., Jr, Nakazawa, F., Ikeda, T., Sato, M., Sato, T. \& Hoshino, E. (1996a). Eubacterium exiguum sp. nov., isolated from human oral lesions. Int J Syst Bacteriol 46, 1120-1124.

Poco, S. E., Jr, Nakazawa, F., Sato, M. \& Hoshino, E. (1996b). Eubacterium minutum sp. nov., isolated from human periodontal pockets. Int J Syst Bacteriol 46, 31-34.

Saitou, N. \& Nei, M. (1987). The neighbor-joining method: a new method for reconstructing phylogenetic trees. Mol Biol Evol 4, 406-425.

Sato, T., Hoshino, E., Uematsu, H. \& Noda, T. (1993a). Predominant obligate anaerobes in necrotic pulps of human deciduous teeth. Microb Ecol Health Dis 6, 269-275.

Sato, T., Sato, M., Matsuyama, J., Kalfas, S., Sundqvist, G. \& Hoshino, E. (1993b). Restriction fragment-length polymorphism analysis of $16 \mathrm{~S}$ rDNA from oral asaccharolytic Eubacterium species amplified by polymerase chain reaction. Oral Microbiol Immunol 13, 23-29.

Slayne, M. A. \& Wade, W. G. (1994). The humoral response to asaccharolytic Eubacterium species in periodontitis. Microb Ecol Health Dis 7, 283-286.

Sundqvist, G. (1976). Bacteriological studies of necrotic dental pulps, pp. 1-92. Dissertation no. 7, Umea University.

Tew, J. G., Marshall, D. R., Moore, W. E. C., Best, A. M., Palcanis, K. G. \& Ranney, R. R. (1985). Serum antibody reactive with predominant organisms in the subgingival flora of young adults with generalized severe periodontitis. Infect Immun 48, 303-311.

Tolo, K. \& Jorkjend, L. (1990). Serum antibodies and loss of periodontal bone in patients with rheumatoid arthritis. J Clin Periodontol 17, 288-291.

Tolo, K. \& Schenck, K. (1985). Activity of serum immunoglobulins $\mathrm{G}, \mathrm{A}$ and $\mathrm{M}$ to six anaerobic oral bacteria in diagnosis of periodontitis. J Periodontal Res 20, 113-121.

Uematsu, H. \& Hoshino, E. (1992). Predominant obligate anaerobes in human periodontal pockets. $J$ Periodontal Res $\mathbf{2 7}$, $15-19$.

Uematsu, H., Nakazawa, F., Ikeda, T. \& Hoshino, E. (1993). Eubacterium saphenum sp. nov., isolated from the human periodontal pockets. Int J Syst Bacteriol 43, 302-304.

Wade, W. G., Moran, J., Morgan, J. R., Newcombe, R. \& Addy, M. (1992). The effects of antimicrobial acrylic strips on the subgingival microflora in chronic periodontitis. $J$ Clin Periodontol 19, 127-134.

Wade, W. G., Lewis, M. A. O., Cheeseman, S. L., Absi, E. G. \& 
Bishop, P. A. (1994). An unclassified Eubacterium taxon in acute dento-alveolar abscess. J Med Microbiol 40, 115-117.

Wade, W. G., Downes, J., Dymock, D., Hiom, S. J., Weightman, A. J., Dewhirst, F. E., Paster, B. J., Tzellas, N. \& Coleman, B. (1999). The family Coribacteriaceae: reclassification of Eubacterium exiguum (Poco et al. 1996) and Peptostreptococcus heliotrinreducens (Lanigan 1976) as Slackia exigua gen. nov., comb. nov. and Slackia heliotrinireducens gen. nov., comb. nov., and Eubacterium lentum (Prevot 1938) as Eggerthella lenta gen. nov., comb. nov. Int J Syst Bacteriol 49, 595-600.

Willems, A., Amat-Marco, M. \& Collins, M. D. (1996). Phylogenetic analysis of Butyrivibrio strains reveals three distinct groups of species within the Clostridium subphylum of the Gram-positive bacteria. Int J Syst Bacteriol 46, 195-199. 